\title{
FORUM
}

\section{Reclaiming Meillassoux for the age of financialization}

\author{
Hadas Weiss
}

\begin{abstract}
My goal in this forum essay is to brush the dust off Claude Meillassoux's (1981) magnum opus, Maidens, Meal and Money, by demonstrating its relevance for the present day. While Meillassoux wrote primarily about precapitalist agricultural communities, he had sketched on their basis a model of social reproduction that incorporates social investments and powers, and he foregrounded the hierarchical and exploitative reproductive orders by which capitalism sustains accumulation. In the context of a renewed interest by feminist scholars in questions of social reproduction, I argue that the analytical tools developed by Meillassoux are at least as helpful in making sense of the age of financialization.
\end{abstract}

Keywords: capitalism, Claude Meilllassoux, domestic community, financialization, social reproduction

In an obituary for Claude Meillassoux, Bernard Schlemmer (2005) tells of an anthropologist streaming into Café LaSorbonne, feverishly branding a journal with one of Meillassoux's early publications and exclaiming, "I have just discovered the article that will change the face of anthropology." Meillassoux's revelation for anthropologists of his time, Schlemmer explains, was that the indigenous societies they studied were forced, like any other, to enter the chain of production before they could function on any other level. Meillassoux made it his life's work to foreground production and its counterpart, social reproduction, as touchstones for explaining all other social phenomena. Yet, the face of anthropology has not been changed, while pro- duction and social reproduction have remained marginal to the field.

But anthropologists are now catching up. Feminist scholars are leading a renewed interest in questions of social reproduction. They attend to the provision of housing, livelihoods, and care for workers and their families, which may occur outside the circuit of commodity production but is nevertheless essential to it (Bhattachayra 2017). Underlining the unpaid care work of women, they hark back to a time when it had been subsidized for more privileged workers through a family wage, a standpoint from which they criticize the commodification and privatization that now forces the least protected women to perform this kind of work in 
the homes of others (Bakker 2007; Bezanson and Luxton 2006; Newberry 2006; Ong 1999). Nancy Fraser (2016) identifies this as a crisis of care. She argues that the care work necessary to produce new generations of workers and replenish existing ones, which has been feminized and separated from formal and remunerated work, is just as indispensable for economic production. Yet the pressures exacted by financialization turn care work into the sole responsibility of families and communities, while at the same time diminishing their capacity to perform it.

Contemporary pressure on care work is matched, however, by the proliferation of financial instruments and strategies designed to help workers reproduce their households, in the sense of securing their own and their children's well-being and future. Credit cards, installment plans, mortgages, and other long-term loans-along with financial management and reinvestment of bank savings, insurance, and pension-permeate the population of financialized economies. They enable workers to invest in higher education, buy homes, purchase private insurance policies, and save privately for their retirement in order to protect against risk and hardship. Caretakers, employers of care work, and working households more generally are activated as potential savers, owners, and investors whose loans, credit, installment plans, and expert risk management would allow them to meet their lifelong goals and help their children do the same.

But even as they provision for the future through financial means, they remain exploited as workers and face new risks as savers. Wherever property and services can be bought with lower incomes, wages are lowered. Wherever household wealth appears in the form of mortgage and credit card debts, bank loans, owned homes, insurance policies, and pension savings, households are vulnerable to fluctuations in the value of these assets. And wherever workers are made to save and insure privately, public goods and services can be rolled back. Financial markets spread household saving and repayment streams by bundling and repackaging them as capital for investment. Their value is calculated with consideration of risks that include the growth-dampening effects of class struggle, political protections, and the inability of debtors to service their loans. The value of the financial instruments that workers use in order to access higher education, homes, pension, health care, and so on is thereby determined by the pace of accumulation. Paradoxically, saving and investing financially in the reproduction of one's household is tantamount to investing in the exploitation and subjugation on which accumulation depends, precipitating an "exploitation of each over all" (Martin 2002: 190) that renders financialization "cannibalistic" (Soederberg 2010; c.f. Sotiropoulos et al. 2013).

Anthropology needs a framework through which to make sense, not only of the crisis of care but also of instances where workers' efforts to reproduce their households are synchronized with the logic of financial accumulation. This requires a closer look at the process of social reproduction and how it shapes and is in turn reshaped by individual investments in it. Rather than reinventing the wheel, they can mine their neglected repository for insight. Meillassoux wrote primarily about precapitalist agricultural communities, but in sketching on their basis a model of social reproduction that incorporates social investments and powers, and in foregrounding the reproductive orders by which capitalism sustains accumulation, he developed analytical tools that can help make sense of the present moment. My goal here is to brush the dust off Meillassoux's (1981) magnum opus, Maidens, Meal and Money, and demonstrate its relevance for the era of financialization.

\section{Meillassoux revisited}

In the introduction to Maidens, Meal and Money, Meillassoux (1981) contrasts his efforts to those of his contemporary, Marshal Sahlins. In Stone Age Economics, Sahlins qualifies primitive economies as domestic modes of production made up of households that produce their means of 
livelihood. They would have manifested the principle drafted by the economist Alexander Chayanov, of working only as hard as they must in order to meet their subsistence needs. Sahlins calls this a Zen attitude to work, where desires are few and fulfilling them is not too difficult. He imagines Stone Agers living in affluence with a relaxed pace of work, ample leisure time, and a relatively nutritious diet. They would have had no reason to change were it not for some pursuing political goals by forcing others to intensify production. At his most daring, Sahlins portrays primitive society as an anti-society (1972: 86), which, absent political imposition, is made up of so many unbound and uncoordinated units of self-concern (95). He considers this anarchic, centrifugal state of nature as being the deep structure of the economy (97).

Faulting Sahlins for recognizing only private forms of production and appropriation, Meillassoux claims that his domestic community lacks coherence and durability (1981: 6). What is to keep self-producing domestic units from falling apart? According to Sahlins, they intensify production only with the imposition of political power. But granting their easy-to-satisfy needs and ample leisure time, why should such power ever emerge? And even if it were to emerge, how would it maintain itself against the overwhelming self-concern of its subjects? Meillassoux further notes that Sahlins nowhere specifies a historical period to which his domestic community applies. He immediately concedes, however, that the same criticism could be leveled against him (7). The sweeping generality of both quasi-historical accounts is, in fact, glaring. But arguably, Meillassoux, like Sahlins, cared less about compiling an accurate record of a distant past than about unearthing the subterranean workings of the present. I follow his lead by forgoing a fact checking of his empirical claims. Taking them at face value, I want to revisit the model that Meillassoux constructs in a way that prefigures the peculiarities of the present.

Instead of scaling up from the domestic unit, as Sahlins does, Meillassoux begins with the means by which a collectivity might produce its livelihood. This shifts the perspective from production per se to reproduction, or the regular repetition of the production and distribution of resources among people in a way that creates a society that transcends and outlives them. Meillassoux (1972) puts forth the primacy of reproduction in the sense of a temporality that carries over an act beyond its enactor. In Maidens, Meal and Money, he substantiates this in terms of "producing subsistence goods-the means of producing human energy - and distributing this energy in the productive cycle, i.e. between the past, present, and future producers" (1981: 51), and he puts forth that this temporality hinges on patterned interdependence.

Meillassoux grounds his argument by imagining a Neolithic agricultural community whose livelihood is based on seasonal cultivation. Like Sahlins, he calls it a domestic community. He contrasts it to hunters and gatherers who form ad hoc alliances for tasks beyond which there is nothing binding them together. Not so with Neolithic farmers. Even when producing for themselves alone, the protracted nature of seasonal agriculture makes them interdependent. To permit the launching of an agricultural cycle, grain must be available during non-harvest time. It must also be available year-round to feed workers as well as children, to ensure that there always will be willing and available workers. Prior investment of energy in land and crop must therefore be stored and distributed in an organized way. Agricultural production requires continuity and an organized waiting period until the produce ripens. Its slow rhythm binds producers together throughout the agricultural cycle.

Able-bodied workers work more than the amount necessary to feed themselves. They do so not merely for their consumption off-season but also for their consumption when they can no longer work and must rely on others. Their work feeds nonworking children and the elderly, and it provides seed for the next crop. In turn, they are indebted to their predecessorsthe group's elders-for the food they ate when growing up and for the seed they now reap and sow. Lifelong relations and mutual commit- 
ments are forged through the investment of energy and advancement of product from one season and from one generation to the next.

Given demographic imbalances and unpredictability in crop, a single household is too small to provide for itself over time in this way. Resources must therefore be distributed between households. In a society that produces for its own needs, redistribution evens out resources. Each household needs a workforce big enough to make optimal use of its land, seed, and other resources, but it gains nothing by producing more than what its consumers need. Over time, then, resources flow to those who use and consume them such that production matches their reproduction.

Neolithic farmers regulate this flow by exchanging women. ${ }^{1}$ They track this exchange through bridewealth-a durable token of a bride owed for a bride given. To prevent bridewealth from being accumulated to the advantage of some over others, elders regulate bridal exchanges, making sure that bridewealth is destroyed once claims are met. Elders' management roles in negotiating marital exchanges and establishing relations of protection and alienation among bride-exchanging groups, grant them power and authority. This authority is upheld through ideologies and rituals that celebrate age, ancestors, and fertility. "The domestic community's social reproduction is not a natural process," Meillassoux insists. "It is a political enterprise" (1981: 46). Elders who feed off others' work have a vested interest in the success of social reproduction, and they acquire the power to regulate distribution in a way that sustains it. This power to sustain society, in the sense of an interdependence maintained across and beyond specific lives, also emerges from it.

Social reproduction for Meillassoux is this dependence of present consumption on past investment and of future consumption on present investment: the activation of material and human resources for their own replenishment. Far from being politically neutral, a reproductive order determines which agents and agen- cies the reproduced society will empower and at what and whose cost. This is immediately suggestive in the context of financialization. In a financialized society, workers repay mortgages on homes and divert portions of their earnings into savings accounts and pension funds, invested by banks and insurers in financial markets. The finance sector imagines that, just as workers inject global markets with liquidity, they are enfranchised with assets whose value hinges on the growth of these markets. Pooled household capital can flow to profitable enterprise, turning each saving and investing worker into a component of the surplus who is able to draw on it in proportion to the size of their investment (Clarke 1994). But larger rewards for larger investors multiply their resources relative to smaller ones, and hence their power over them. At the same time, capital is channeled to enterprises where it grows and away from those where it does not, making competition bear down hard on workers and extract ever more material and physical resources. Meillassoux highlights not only power and hierarchy but also exploitation, insofar as investors lose in an absolute sense (rather than just relative to larger investors) as society reproduces itself at their expense. This is nowhere more evident than when he turns his gaze to capitalism.

\section{Meillassoux on capitalism}

Meillassoux relates social reproduction to Karl Marx's idea of an equalization in the rate of profit. For Marx, profit is the portion of the surplus value that capitalists pocket as their reward for enterprise. Capitalists invest in the branches that promise the highest returns. Capital is thereupon increased in those branches, depressing the price of their products and ultimately their profitability, driving capitalists to invest elsewhere. The effect is to even out the rate of profit between investment opportunities, spreading capital more widely. Meillassoux stretches Marx's analytic to explain modern so- 
cial security: a portion of the surplus is redistributed among unemployed, ill, disabled, and retired workers as a way of reproducing the workforce when work incomes are interrupted (1981: 102-103, 156).

Here, Meillassoux departs from Marx. A mainstay of Marx's theory is the unity of production and reproduction. "If production has a capitalist form, so too will reproduction," he writes in Capital (1990: 711). In contrast, Meillassoux suggests that capitalism outsources reproduction to a modern version of a domestic community-he identifies it with seasonal migrant labor and with welfare arrangementswhich continues to operate within the capitalist system. Bridget O'Laughlin (1977) faults him for resurrecting reproduction in this rather biological sense when capitalism does not necessitate it. To reproduce itself, capitalism requires only that surplus be created and reinvested in the next cycle of production, that is, that more value is produced than what is spent on labor power. Indeed, the smaller the portion of value fed back to the workforce, the larger the surplus. Competing capitalists try to substitute machinery for living labor, creating a population redundant to production, which may be allowed to go hungry. Meillassoux recognizes such redundancies but nonetheless finds reproductive orders persisting alongside capitalism.

It is so with the French social security system that Meillassoux reflects on. He sees it as providing for employees beyond a minimum wage, which is calculated to cover the needs of a bachelor working without interruption. Social security converts a portion of the surplus value-for example, by levying taxes on profits and assetsinto goods and services beyond what this wage can buy. They are to include the worker's dependents as well as periods of unemployment, enabling an entire workforce to be sustained and reproduced. This analysis resonates with feminist scholarship on social reproduction, which goes on to argue that such deployment of the surplus value relegates women to unpaid domestic work.
Since the time Meillassoux was writing, the economic and political costs of social security have risen. Inequality generates uneven public support for redistribution, and global investors put checks on state spending. The workforce in financialized economies is steered toward global finance on the one hand and family resources on the other, as means of reproducing themselves in the absence of public support. Meillassoux could not have foreseen this. He recognizes that "the reproduction of labor-power ... ought logically to be an investment, and therefore part of capital," but he is troubled by the fact that "under capitalism the wage-earner's income which comes to him in return for work cannot be composed of capital without the worker becoming, ipso facto, a capitalist" (1981: 101-102). The duality for which O'Laughlin takes him to task resurfaces in his positing of a stark opposition between capitalists and workers, whereby capitalists own revenue-generating assets while workers are exploited pure and simple. Indeed, Meillassoux suggests that each class possesses its own mode of reproduction (81).

But, contra Meillassoux's dualism, the boundary between workers and capitalists is increasingly porous. Workers are implicated in the flow of capital when they receive credit cards and bank loans, when they possess assets and manage balance sheets, and when their banks, insurers, and pension funds invest their savings in global enterprise. The savings, assets, and investments of workers are thereupon valued according to the success of capital in generating a surplus. The concomitant exacerbation of social inequality pressures them to take on debt and try to procure the assets that would give them a leg up over others who compete for the same resources. And just as work earnings alone do not suffice to secure their futures, hardly anyone can afford to live solely off interests, dividends, and rent, such that they must continue to work. Even more efficiently than through social security arrangements, capitalism is reproduced when exploited workers can only provide for their households by investing in it. 
Financialization thus reproduces society in a form more invasive and exploitative than Meillassoux envisions. Still, his model of an investment-driven redistribution allows him to recognize institutions like social security, and us to recognize widespread if uneven access to credit and property, as something other than concession to workers' demands. The two-way investment model that Meillassoux constructs with reference to his Neolithic farmers-of agents investing in their natural and social resources and of society becoming a durable entity by orchestrating their investments in it-alerts us to how global finance can infuse the social body, despite the immense differences between the structure of Neolithic societies and that of capitalist ones.

Meillassoux also writes about migrant labor. His aim is "connecting it with the problem of the expansion of capitalism (as raised by Rosa Luxemburg)" (1981: xii). What Marx called primitive accumulation-the direct expropriation of small producers-has been ongoing in colonies. Luxemburg argued that capitalist production exhausts demand on its original terrain and seeks, in colonies, new outlets in which to realize the value of its commodities. Meillassoux transposes the overproduction of commodities to that of labor power: a population growing in excess of the work that it is required to perform by profit-oriented industrial production. An optimal condition for capitalism to reproduce itself is a steady stream of productive workers whose upkeep does not deplete too much of the surplus. One way of meeting this requisite is with migrant and seasonal labor: miners and factory workers living on farms and only exiting them when their work is in demand. Farms feed and house a reserve of cheap labor for hire, allowing employers to pay these workers only the wages necessary to cover their actual work time.

This comes closest to the contemporary understanding of social reproduction as the unpaid work of women who, filling a role equivalent to that of such farms, birth the next generation of workers, provide their domestic needs, and care for those who have left the workforce. But note an important difference: where much of this scholarship considers social reproduction, in the sense of feminized care work, a condition of possibility for capitalist accumulation (Fraser 2016), Meillassoux underlines contingent and varying reproductive orders that support accumulation. He never claims that workers' needs must necessarily be met. Capitalist accumulation requires underpaid labor, but its changing nature also influences how much of this labor can actually be used in each production cycle, what kind of labor it must be, and how best to access and exploit it. Technological changes might reduce the amount of workers necessary, just as they might do away with the domestic community. The integration of domestically produced agriculture in a capitalist economy, according to Meillassoux, persists only so long as its ability to sustain labor reserves outstrips the demand for highly productive agriculture to feed larger swaths of the workforce elsewhere and under different conditions (1978: 168-169).

Meillassoux thereby anticipates Simon Clarke's (1994) critique of Luxemburg and her circle for assuming the preexistence of demand as a condition for accumulation and its end point. They fall into the trap of bourgeois economics, Clarke maintains, by supposing that production always adjusts itself to the limits of the market. That "consumption is the sole end and purpose of all production," Adam Smith proclaimed, is "so self-evident that it would be absurd to attempt to prove it" (2009: 391). Yet, Marx showed that capitalist production serves the accumulation of surplus, not the satisfaction of needs. Competition compels capitalists to produce beyond the limits of the market. The value of production is realized not through the consumption of workers but through profitable investment, that is, by the demands of capital. Only when overproduction hinders accumulation do the limits of the market reimpose themselves in incomplete and socially destructive ways, with financialization being the most recent strategy for rekindling profitability. 


\section{Reproducing capitalism}

Another way of framing Meillassoux's discussion of capitalism is that social reproduction, taking shape as a reproductive order, supports accumulation but is neither its goal nor necessarily its condition of possibility-hence the growing rates of exploitation and the proliferation of an impoverished surplus population. This chimes with Melinda Cooper's (2017) recent critique of social reproduction theories. Their concern over a crisis of care, Cooper argues, often amounts to a revalorization of women's role as nurturers. In wanting women to be equitably remunerated for it, they miss a prior moment-described most famously by Silvia Federici (2004) - in which women were assigned a reproductive role in the first place, forged in contradistinction to a productive one. Cooper refocuses on the various reproductive orders (from nation through race to family) through which various workers have sought protection on the grounds of their assumed priority and even naturalness. She reminds us that these orders are themselves subordinate to capitalism's logic of accumulation and remain operative only to the extent that they normalize it. They do so by allowing actors who are more powerful to consolidate their relative advantages, whether workingmen their power over women, or propertied families their right to transmit privileges to their children. It is therefore the reproductive order and the inequalities in wealth and power that it undergirds, which reinforces given forms of social reproduction.

In tracing social reproduction through the mutual investments of those it implicates, Meillassoux never loses sight of its losers. This holds true even among Neolithic farmers. He considers women, for example, to be irredeemably exploited in this society. Important as they are for its reproduction, they obtain neither status nor power, and they are awarded significance only through the mediation of men (1981: 77). Meillassoux sees exploitation intensifying when workers are dispossessed of the means of pro- duction. But he distinguishes inequality from exploitation. Neolithic elders enjoyed power and other advantages over the juniors in their community, but they did not exploit them. Their privileges were ultimately turned over to younger men. In turn, even powerless young men who worked to feed others were granted wives and would succeed elders to recover the product of their work within their own lifetimes (78-79).

What would society look like if all members were incorporated into it in this way, that is, as debtors or beneficiaries of investment who are ultimately and sometimes simultaneously also creditors or investors? Advocates of financialization consider it as fostering such incorporation: recipients of loans are also owners, savers, and investors who possess claims against the growth of capital and are therefore direct beneficiaries of accumulation. Meillassoux's account helps to demystify this assertion because he demonstrates how particular social relations, whether lateral or hierarchical, might gel and stick despite the havoc they wreak on the entire population. He insists that what is being reproduced is not society pure and simple but rather a reproductive order. This order-it bears repeating-is hierarchical and exploitative. The reconstitution of domestic units is optimal only in the absence of saving through money and durable valuables (57). Capitalism severs the fates of these units from one another, making them vulnerable to redundancy. Meillassoux goes so far as to describe the concentration camps of Nazi Germany as means of disposing a surplus population (140). Yet, he also takes pains to show how capitalism's production of a surplus manifests itself as a dynamic that works through the isolated interests of competing actors by introducing pressures as well as incentives.

When capitalism is reproduced, what it reproduced is not society in the first instance but rather the surplus that would launch the next cycle of production. And surplus is generated by workers producing more value than they receive 
for their work. The reproduction of capitalism can therefore never be a harmonious matching of advances and returns, even over lifetimes. This is true insofar as a small number of capitalists accrue great fortunes at the expense of penniless masses. It is also true in the cases that Meillassoux discusses, where colonial employers pay migrants for their labor and throw them back on their communities off-season, or where social security allows employers to pay workers minimally. But it is perhaps especially true in financialized societies. Even if, ideally, every worker stands to gain by investing in the capital pooled in global markets, these revenues are generated by the deterioration of working conditions and by the extraction of natural resources. Since hardly anyone can make a living without working, more and more segments of the working population are drawn into a vicious cycle in which they are forced to invest in their own exploitation.

The generalization of exploitation across a population unwittingly caught up in it as both its subjects and its objects is the real novelty of financialization. Workers since the dawn of capitalism have had a stake in the survival of their workplaces insofar as they depended on the wages they made there. Still, neither the economic success of their employers nor economic growth more generally would have translated in any direct way into a rise in their standards of living. Such disparity gave workers some leverage to resist their exploitation. But with financialization, accumulation is framed as a public interest insofar as the workforce is redefined as an investing public. One need only recall the fallout of the most recent financial crisis to see this in action. The bursting of the real estate bubble and the collapse of big corporations priced millions out of their homes and depleted their retirement savings, yet the banking sector was bailed out against the backdrop of grave warnings that its collapse would wipe out the savings of millions more. Financialization represents the most generalized form of capitalism: the conflation of its own reproduction with "social reproduction" and, by extension, of its own logic with society itself. Reproductive orders must therefore be understood along with the powers and contradictions they generate. Maidens, Meal and Money is a good place to start.

\section{Acknowledgments}

I would like to thank the Focaal editorial team and anonymous reviewers for helping me shape this into something publishable. Thanks also to Amanda Englert, Yaqub Hilal, and Matan Kaminer, who offered valuable advice on early drafts, and to Malcolm Blincow, whose excellent suggestions helped me improve the final version.

Hadas Weiss is a research fellow at the Madrid Institute for Advanced Study. Her ethnographic research deals with the social underpinnings and fallouts of financialization in Israel and Germany.

Email: hadaspwess@gmail.com

\section{Note}

1. Meillassoux maintained that women's limited fertility relative to that of men makes their circulation the more efficient form of reproduction, condemning them to subordination-a claim that has drawn justified heat for its biologically deterministic account of gender inequality (Donham 1999; Katz 1983; O’Laughlin 1977).

\section{References}

Bakker, Isabella. 2007. "Social reproduction and the constitution of a gendered political economy." New Political Economy 12 (4): 541-556.

Bezanson, Kate, and Meg Luxton, eds. 2006. Social reproduction: Feminist political economy challenges neoliberalism. Montreal: McGill-Queen's University Press. 
Bhattachayra, Tithi, ed. 2017. Social reproduction theory: Remapping class, recentering oppression. London: Pluto Press.

Clarke, Simon. 1994. Marx's theory of crisis. London: Palgrave Macmillan.

Cooper, Melinda. 2017. Family values: Between neoliberalism and new social conservatism. Cambridge, MA: MIT Press.

Donham, Donald. 1999. History, power, ideology. Berkeley: University of California Press.

Federici, Silvia. 2004. Caliban and the witch. Brooklyn, NY: Autonomedia.

Fraser, Nancy. 2016. "Contradictions of capital and care." New Left Review 100: 99-117.

Katz, Cindy. 1983. "Book review: Maidens, meal and money." Antipode 15 (1): 42-45.

Martin, Randy. 2002. Financialization of everyday life. Philadelphia: Temple University Press.

Marx, Karl. 1990. Capital: A critique of political economy, vol. 1. Trans. Ben Fowkes. London: Penguin.

Meillassoux, Claude. 1972. "From reproduction to production: A Marxist approach to economic anthropology." Economy and Society 1 (1): 93-105.

Meillassoux, Claude. 1978. "The social organization of the peasantry: The economic basis of kinship." In Marxism and anthropology: A preliminary survey, ed. David Seddon, 159-169. Tolowa, NJ: Frank Cass.
Meillassoux, Claude. 1981. Maidens, meal and money: Capitalism and the domestic community. Cambridge: Cambridge University Press.

Newberry, Jan. 2006. Back door Java: State formation and the domestic in working class Java. Toronto: University of Toronto Press.

O'Laughlin, Bridget. 1977. "Production and reproduction: Meillassoux's femmes, greniers et capitaux." Critique of Anthropology 2 (8):3-32.

Ong, Aihwa. 1999. Flexible citizenship: The cultural logics of transnationality. Durham, NC: Duke University Press.

Sahlins, Marshall. 1972. Stone age economics. New York: Aldine.

Schlemmer, Bernard. 2005. "A tribute to Claude Meillassoux." Trans. Edgard Sankara. Africa Dialogue 281. http://www.laits.utexas.edu/africa/ ads/281.html.

Smith, Adam. 2009. An inquiry into the nature and causes of the wealth of nations. New York: Digireads.com

Soederberg, Susanne. 2010. "Cannibalistic capitalism: The paradoxes of neoliberal pension securitization." Socialist Register 47. https:// socialistregister.com/index.php/srv/article/ view/14337.

Sotiropoulos, Dimitris, John Milios, and Spyros Lapatsioras. 2013. A political economy of contemporary capitalism and its crisis: Demystifying finance. New York: Routledge. 